\title{
Antidepressant effects of total tertiary alkaloid fraction of Cissampelos sympodialis Eichler in rodents
}

\author{
Sueli Mendonça-Netto, Rogério W. B. Varela, Madge F. Fechine, Marcello N. G. Queiroga, \\ Flávia N. Souto-Maior, Reinaldo N. Almeida*
}

\author{
Universidade Federal da Paraíba, Laboratório de Tecnologia Farmacêutica, Caixa Postal 5009, 58051970 \\ João Pessoa-PB, Brazil
}

\begin{abstract}
RESUMO: "Efeitos antidepressivos da fração de alcalóides terciários totais de Cissampelos sympodialis Eichler em roedores". A proposta deste trabalho foi de avaliar os efeitos da fração de alcalóides terciários totais (TTAF) de Cissampelos sympodialis Eichler (Menispermaceae) em dois modelos animais de depressão: a) teste do nado forçado e b) teste da reserpina. O tratamento de camundongos com TTAF $(12,5 \mathrm{mg} / \mathrm{kg})$ reduziu o tempo total de imobilidade dos animais. Também reverteu a hipotermia induzida por reserpina, demonstrando um efeito antidepressivo nos dois modelos. Adicionalmente, o tratamento com TTAF não modificou a ambulação e o comportamento de levantar das patas dianteiras dos animais avaliados no teste do campo aberto, realizado no intuito de investigar se a redução no tempo de imobilidade apresentada no teste do nado forçado foi causada por estimulação na atividade locomotora. Como a warifteína é um dos principais alcalóides presente na TTAF da C. sympodialis, e tem atividade inibidora da enzima fosfodiesterase, ela pode ser responsável pelo efeito antidepressivo observado na fração estudada.
\end{abstract}

Unitermos: Cissampelos sympodialis, Menispermaceae, atividade antidepressiva, fração de alcalóides terciários totais.

\begin{abstract}
The purpose of the present study was to evaluate the effects of total tertiary alkaloid fraction (TTAF) of Cissampelos sympodialis Eichler (Menispermaceae) on two animal models of depression: a) forced swim test and b) reserpine test. Treatment of mice with TTAF (12.5 $\mathrm{mg} / \mathrm{kg}$ ) reduced the total immobility time. It also reversed the reserpine-induced hypothermia, demonstrating an antidepressant effect in both models. Additionally, TTAF treatment did not modify the ambulation and rearing evaluated in open field test in order to investigate if the immobility time reduction found in the forced swimming test was caused by locomotive activity stimulation. Since warifteine is one of the main alkaloids present in the TTAF of C. sympodialis, and it has inhibitory activity of the phosphodiesterase enzyme, it may be responsible by the antidepressant effect found in the fraction studied.
\end{abstract}

Keywords: Cissampelos sympodialis, Menispermaceae, antidepressant activity, total tertiary alkaloids fraction.

\section{INTRODUCTION}

Cissampelos sympodialis Eichler, plant of the Menispermaceae family, grows in the humid areas of northeast Brazil. Its roots are popularly used by infusion or decoction against cough, bronchitis, asthma, arthritis and urinary infections (Corrêa, 1984; Agra et al., 2007, Porto et al., 2008). Thomas et al. (1995) demonstrated that the hydroalcoholic extract of the roots presents a relaxant effect on guinea-pig trachea muscle indicating the pharmacological basis of its folk use against asthma. Assis et al. (2001) showed that the daily oral administration (p.o.) of the aqueous fraction of the ethanol extract of $C$. sympodialis leaves (AFL) was devoid of any toxicological effect. Similar results also were observed in dogs after an AFL subacute treatment (Diniz et al., 2002).

The chemical study of $C$. sympodialis led to the isolation of six tertiary alkaloids: warifteine, methylwarifteine, roraimine, liriodenine and milonine, (Freitas et al., 1995; Freitas et al., 1999; Barbosa-Filho et al., 1997; Lira et al., 2002; Bezerra-Santos et al., 2006), and one quaternary alkaloid, laurifoline (Barbosa-Filho et al., 1997).

Cytotoxic effects of isolated warifteine and milonine were demonstrated in cultured hepatocytes and V79 fibroblasts. However, milonine was less toxic than warifteine in both cell cultures (Melo et al., 2003).

It has been shown that oral treatment with Cissampelos sympodialis extract has an immunomodulatory effect, reducing allergy-associated responses (Bezerra-Santos et al., 2004; 2005), and in recent study, Bezerra-Santos et al. (2006) and Costa et al. (2008) suggested that $C$. sympodialis and warifteine may be a promising anti-allergic therapy, inasmuch as it presents potent anti-eosinophil and anti-leukotrienes 
activities.

Literature data have reported the use of antidepressants to treat bronchitis and asthma, suggesting an involvement of the bronchial amines in the manifestation of the disease (Lechin et al., 1998).

Previous studies had demonstrated that the ethanol extract of $C$. sympodialis leaves increased the toxicity of pentylenetetrazol in mice, reduced the time of immobility in the forced swimming test, and reversed the degree of ptosis and reserpine-induced catalepsy in rats. These results suggest that the extract possess an antidepressant effect and an inhibitory activity of the nuclear cyclical enzyme phosphodiesterase (PDE) with a consequent increase of the levels of cAMP in the brain (Almeida et al., 1998).

Therefore, the present work was designed in order to evaluate a possible antidepressant activity of the total tertiary alkaloids fraction (TTAF) of $C$. sympodialis leaves.

\section{MATERIAL AND METHODS}

\section{Plant material}

C. sympodialis specimens were primarily collected in the city of Souza, Paraíba, Brazil, and identified by Dr. Maria de Fátima Agra. A voucher specimen (Agra-1456) was deposited at Herbarium Prof. Lauro Pires Xavier of the Universidade Federal da Paraíba (UFPB).

\section{Total tertiary alkaloid fraction preparation}

The leaves were from the botanical garden of the Laboratório de Tecnologia Farmacêutica (LTF) of Universidade Federal da Paraíba (UFPB) and submitted to a drying process at $50{ }^{\circ} \mathrm{C}$. Later the leaves were pulverized and the powder was extracted with $70 \%$ ethanol in water at $70{ }^{\circ} \mathrm{C}$ for 5 days. The dried extract was dissolved in water, filtered and known volumes were dried to determine the final concentration of the watersoluble components. All doses are expressed in terms of the concentration of the soluble components $(\mathrm{mg} / \mathrm{kg}$ of body weight). The yield was $22 \%$ on average, based on solid residues present. The hydroalcoholic extract from C. sympodialis was submitted to procedures in order to obtain the TTFA, using column and thin layer chromatography. Briefly, the extract was dissolved in $3 \% \mathrm{HCl}$ and extracted several times with $\mathrm{CHCl}_{3}$. The aqueous fraction was basified with $\mathrm{NH}_{4} \mathrm{OH}$ to $\mathrm{pH} 9$ and again extracted with $\mathrm{CHCl}_{3}$. The chloroform phase was rinsed with water, dried in anhydrous $\mathrm{MgSO}_{4}$ and filtered. The solvent was removed under reduced pressure at $40{ }^{\circ} \mathrm{C}$, thus obtaining TTAF (Barbosa-Filho et al., 1997; Cunha et al., 1988).
Male Swiss albino mice (25-30 g) and male Wistar (220-250 g) rats from the biotery of LTF/UFPB were used. The animals were kept in polypropylene boxes, covered with sawdust, at controlled temperature $\left(20-22{ }^{\circ} \mathrm{C}\right)$, with a 12 -h light/dark cycle (lights at 6:00 a.m.). They had free access to water and food, except for the reserpine reversion test which the rats were kept under fasting conditions after reserpine treatment. All the experiments were carried out between 09:00 a.m. and 2:00 p.m. Experimental protocols and procedures were approved by the Animal Experimentation Ethics Committee (CEPA)/ LTF.

\section{Drugs}

Imipramine and reserpine were acquired from Sigma Company Ltd, USA. Injections at volume of 1 $\mathrm{mL} / \mathrm{kg}$ in rats and $1 \mathrm{~mL} / 100 \mathrm{~g}$ in mice were administered intraperitoneally (i.p.). At the time of use imipramine, reserpine and TTAF were dissolved in agar.

\section{Forced swimming test}

In this test, the animals were forced to swim in a container from which escape was impossible. After a period of rigorous activity, the animals become motionless, only making the movements necessary to keep their heads out of water (Porsolt et al., 1977a,b).

In a daily pre-test phase, the mice were allowed to swim in a polypropylene box with 11 liters of water at $25{ }^{\circ} \mathrm{C}$. Twenty-four hours later, these animals were divided into groups of 10 each, receiving TTAF (12.5 and $42 \mathrm{mg} / \mathrm{kg}$, respectively $1 / 10$ and $1 / 3$ of $L_{50}$ ), imipramine $(10 \mathrm{mg} / \mathrm{kg}$ ) or agar (agar solution). One hour after the administration, the animals were allowed to swim in a transparent glass cylinder $(18 \mathrm{~cm}$ height, $14 \mathrm{~cm}$ diameter) filled with water $\left(1,5 \mathrm{~L}\right.$, at $\left.25^{\circ} \mathrm{C}\right)$. The latency and the immobility total time were the parameters evaluated during $5 \mathrm{~min}$. After each test, rats were dried with a towel and placed in a separate cage, heated by a $300 \mathrm{~W}$ lamp until the animals were dry.

\section{Reversion of reserpine effect}

Administration of reserpine depletes 5HT, NE and dopamine reserves causing symptoms like ptosis, hypothermia and catalepsy in rats, which are very similar to chronically depressive patients (Hill and Tedeshi, 1971; McKinney, 1976). In our experiments, rats were injected with reserpine $(5 \mathrm{mg} / \mathrm{kg})$, after measuring their basal temperature. The test started eighteen hours after the reserpine injection. The animals were divided into groups of 10 animals each, receiving TTAF 12.5 and 42 $\mathrm{mg} / \mathrm{kg}$, imipramine $(1 \mathrm{~mL} / 100 \mathrm{~g})$ or agar. Their rectal temperature was measured $30,60,120$ and $180 \mathrm{~min}$ after the drugs injection. 

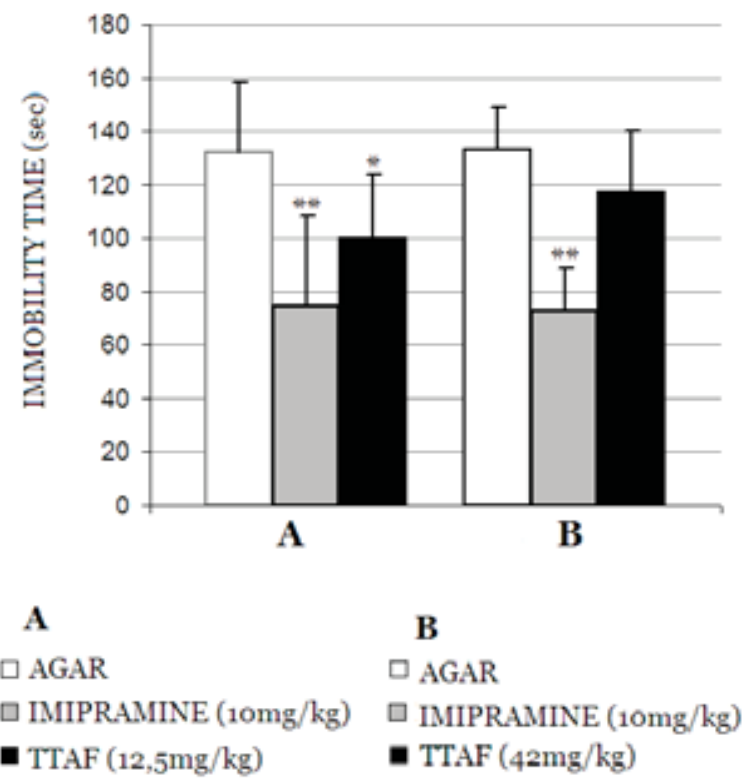

Figure 1. Effect of Cissampelos sympodialis total tertiary alkaloids fraction on the immobility time. Columns represents Mean \pm Standard error of Mean (SEM) of total immobility time of mice in forced swimming test ( $\mathrm{n}=10$ for all groups). Asterisks (*) represent difference between control and other groups. (Student Newman-Keuls Test $* \mathrm{p}<0.05 ; * * \mathrm{p}<0.001$ ).

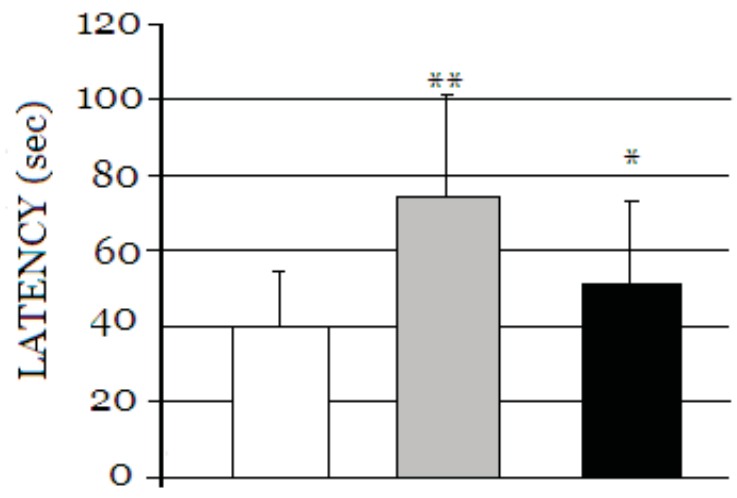

$\square$ AGAR

IMIPRAMINE (10mg/kg)

TTAF $(12.5 \mathrm{mg} / \mathrm{kg})$

Figure 2. Effect of Cissampelos sympodialis total tertiary alkaloid fraction on the latency time. Columns represents Mean \pm Standard Error of Means (SEM) of total time (seconds) of immobility in the forced swimming test ( $\mathrm{n}=10$ for all groups). Asterisks $(*)$ represent significant difference between control and other groups (Student-Newman-Keuls Test, ${ }^{*} \mathrm{p}<0.05$; $* * \mathrm{p}<0.001)$.

\section{Open field test}

An open field apparatus consists of a metal enclosure measuring $55 \mathrm{~cm}$ in diameter, whose floor was round and divided into 3 concentric rings which were subdivided into 16 quadrants, located at. Sidewalls were about $60 \mathrm{~cm}$ high and in the center of the top of the enclosure was a light bulb of 40 watts. The animals were divided into groups of 10 and received TTAF (12.5 $\mathrm{mg}$ ) or agar. One hour later, each rat was placed in the center of the enclosure and the cross squares (number of crossings with four legs across the divisions of the field) and vertical line exploration (rearing) were assessed during the period of $5 \mathrm{~min}$.

\section{Statistical analysis}

The data obtained were evaluated by one-way analysis of variance (ANOVA) followed by StudentNewman-Keuls test. Differences were considered statistically significant when $\mathrm{p}<0.05$.

\section{RESULTS}

\section{Forced swimming test}

TTAF $12.5 \mathrm{mg} / \mathrm{kg}$, i.p. decreased mice immobility time in forced swimming test when compared to the control group (Figure 1). The same effect was not observed at $42 \mathrm{mg} / \mathrm{kg}$. No effect on the latency time in $42 \mathrm{mg} / \mathrm{kg}$ (data not shown was observed). Additionally, TTAF treatment $12.5 \mathrm{mg} / \mathrm{kg}$ showed an increased of latency (Figure 2).

\section{Reversion of reserpine effect}

TTAF $12.5 \mathrm{mg} / \mathrm{kg}$, i.p., significantly diminished hypothermia caused by reserpine in rats at 30, 60, 120 and $180 \mathrm{~min}$ (Figure 3). This effect started $30 \mathrm{~min}$ after injection and persisted throughout the $180 \mathrm{~min}$ duration of the experiment. At $120 \mathrm{~min}$ the standard drug imipramine - had its effect already diminished, whereas that of TTAF presented a great effect.

\section{Open field test}

Significant differences in the cross squares and rearing between TTAF and control groups had not been found (Table 1).

\section{DISCUSSION}

The TTAF of $C$. sympodialis was evaluated in two animal models of depression: forced swimming test and reserpine reversion test. In the forced swimming test, a model of behavioral despair, developed by Porsolt et al (1977a,b; 1978), TTAF $12.5 \mathrm{mg} / \mathrm{kg}$ of C. sympodialis, reduced the total immobility time (Figure 1) and latency time (Figure 2) in mice. Immobility reflects a "state of despair", and drugs belonging to the group of tricyclic antidepressants, atypical antidepressants and MAOI, 


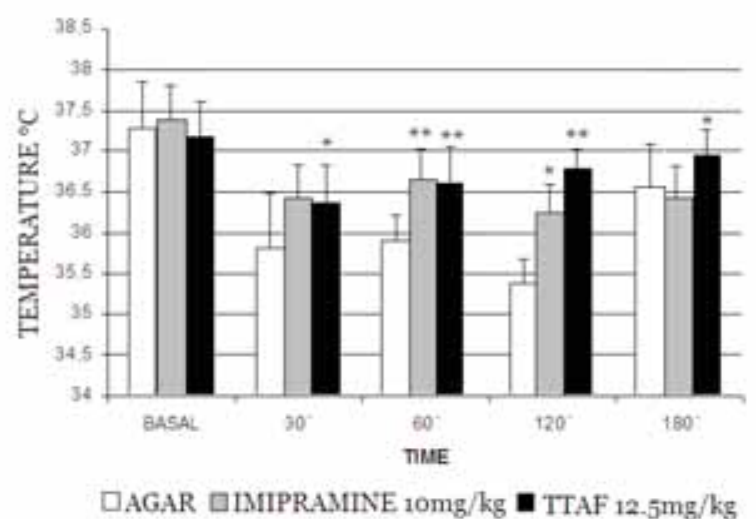

Figure 3. Cissampelos sympodialis total tertiary alkaloid fraction treatment reverting reserpine effect. Columns represent Mean \pm Standard Error of Means (SEM) of test animals temperature $\left({ }^{\circ} \mathrm{C}\right)$, measured at different times in the reserpine test $(\mathrm{n}=10$ for all groups). Asterisk represents significant differences between control and experimental groups (StudentNewman-Keuls Test, ${ }^{*} \mathrm{p}<0.05 ; * * \mathrm{p}<0.01$ ).

electroshock or impairment of paradoxical sleep during $24 \mathrm{~h}$ preceding the test, reduce the time that the animal remains motionless (Porsolt et al., 1993). TTAF $42 \mathrm{mg}$ / $\mathrm{kg}$ did not present any effect on the same test. These data can be related to the predominance of the effect of one alkaloid in the smaller dose and its inhibition in the larger one.

In the reserpine reversion test, TTAF was able to reverse reserpine-induced hypothermia, demonstrating its antidepressant activity (Barros and Leite, 1986). In this test TTAF was found to lengthen is maximum effect at 120 and $180 \mathrm{~min}$, and the reduction of the effect of the standard drug, imipramine, were at $120 \mathrm{~min}$ (Figure 3). These results suggest a lengthier antidepressant action compared to the antidepressant used as standard.

Psychostimulants also reduce the time of immobility in the forced swimming test, though unlike antidepressants, these cause motor stimulation (Porsolt et al., 1977a, 1978). In order to prove that the reduction of immobility time was not caused by the stimulation of motor activity, TTAF was submitted to the open field test (Walsh and Cummins, 1976; Butterweck et al., 1998). When compared to the control group, increased cross squares (ambulation) and rearing were not observed, indicating that antidepressant effect found in the forced swimming test was not bases on the stimulation of locomotor activity.

Warifteine, one of existing alkaloids in the TTAF, is found in high concentration levels in the leaves and bark of the roots. Previous studies have demonstrated that warifteine caused inhibition of the spontaneous tonus of the trachea of guinea-pigs, due to the increase of cAMP, probably by the inhibition the PDE enzyme (Côrtes et al., 1995; Barbosa-Filho et al., 1997; Thomas et al., 1999). Saccomano et al. (1991)
Table 1. Effect of Cissampelos sympodialis total tertiary alkaloid fraction in the open field test.

\begin{tabular}{ccc}
\hline Treatment (i.p.) (mg/kg) & Cross squares & Rearing \\
\hline Agar (control group) & $73.6 \pm 28.7$ & $15.9 \pm 13.6$ \\
FATT $12.5 \mathrm{mg} / \mathrm{kg}$ & $91.8 \pm 30.8$ & $18.5 \pm 12.5$ \\
\hline
\end{tabular}

Values are Mean $\pm \mathrm{SD}(\mathrm{n}=10)$.

have demonstrated that the inhibition of PDE enzyme and consequent increase of cAMP can be responsible for antidepressant effect caused by certain drugs. Therefore, the antidepressant presented effect by the TTAF of $C$. sympodialis leaves may be due to the inhibitory effect the PDE enzyme caused by warifteine.

Studies based on rat aorta (Freitas et al., 1999) suggested that the activation of $\alpha$-adrenoceptors by extract of $C$. sympodialis play a role in the contractions. Several biogenic amines, including noradrenaline, are involved in the etiology of depression.

The current study provides evidences that TTAF of $C$. sympodialis has antidepressant activity. However, new experiments can be carried out to investigate the mechanisms of these effects, and to confirm if warifteine is responsible for the antidepressant activity found in the fraction.

\section{ACKNOWLEDGMENTS}

The authors like to express their sincere thanks to J.C. Duarte for his technical assistance and CNPq and RENORBIO by support to this work.

\section{REFERENCES}

Agra MF, Freitas PF, Barbosa-Filho JM 2007. Synopsis of the plants known as medicinal and poisonous in Northeast of Brazil. Rev Bras Farmacogn 17: 114-140.

Almeida RN, Navarro DS, Assis TS, Medeiros IA, Thomas G 1998. Antidepressants effect of an ethanolic extract of the leaves of Cissampelos sympodialis in rats and mice. J Ethnophamacol 63: 247-252.

Assis TS, Almeida RN, Barbosa-Filho JM, Medeiros IA 2001. CNS pharmacological effects of the total alkaloidal fraction from Albizia inopinata leaves. Fitoterapia 72: 124-130.

Barbosa-Filho JM, Agra MF, Thomas G 1997. Botanical, chemical, pharmacology investigation on Cissampelos species from Paraíba (Brazil). Ciência e Cultura, J Braz Assoc Advanc Sci 49: 386-394.

Barros HMT, Leite JR 1986. The use of rodents in the animal models of depression. Sci Cult 36: 952-958.

Bezerra-Santos CR, Balestieri FMP, Rossi-Bergmann B, Peçanha LMT, Piuvezam MR 2004. Cissampelos sympodialis Eichl. (Menispermaceae): oral treatment decreases IgE levels and induces a Th1-skewed cytokine production in ovalbumin-sensitized mice. $J$ Ethnopharmacol 95: 191-197.

Bezerra-Santos CR, Peçanha LMT, Piuvezam MR 2005. Cissampelos sympodialis Eichl. (Menispermaceae) 
inhibits anaphylactic shock reaction in murine allergic model. Rev Bras Farmacogn 15: 287-291.

Bezerra-Santos CR, Vieira-de-Abreu A, Barbosa-Filho JM, Bandeira-Melo C, Piuvezam MR, Bozza PT 2006. Anti-allergic properties of Cissampelos sympodialis and its isolated alkaloid warifteine. Int Immunopharmacol 6: 1152-1160.

Butterweck V, Petereit F, Winterhoff H, Nahrstedt A 1998. Solubilized hypericin and pseudohypericin from Hypericim perforatum exert antidepressant activity in the forced swimming test. Planta Med 64: 291-294.

Corrêa MP 1984. Dicionário das plantas úteis do Brasil e das exóticas cultivadas. Ministério da Agricultura, IBDF, RJ.

Côrtes SF, Alencar JL, Thomas G, Barbosa-Filho JM 1995. Spamolytic actions of wariteine a bisbenzylisoquinoline alkaloid isolated from the root bark of Cissampelos sympodialis Eichl. (Menispermeaceae). Phytother Res 9: 579-583.

Costa HF, Bezerra-Santos CR, Barbosa Filho JM, Martins MA, Piuvezam MR 2008. Warifteine, a bisbenzylisoquinoline alkaloid, decreases immediate allergic and thermal hyperalgesic reactions in sensitized animals. Int Immunopharmacol In Press, doi:10.1016/j.intimp.2007.11.009.

Cunha EVL, Cornelio ML, Barbosa-Filho JM, Braz-Filho R, Gray AI 1998. Eletefine, a stephaoxocane alkaloid from Cissampelos glaberrima. J Nat Prod 61: 1140-1142.

Diniz MFF, Santos RB, Cunha MAL, Duarte JC, Morais MA, Medeiros IA 2002. Subacute toxicology studies on the aqueous fraction of the ethanol extract of the leaves of Cissampelos sympodialis Eichl. (Menispermaceae) in dogs. Rev Bras Farmacogn 12 (Suppl.): 87-89.

Freitas MR, Alencar JA, Cunha EVL, Barbosa-Filho JM, Gray AI 1995.Milonine, an 8,14-dihydromorphinandienone alkaloid from leaves of Cissampelos sympodialis. Phytochemistry 40: 1553-1555.

Freitas MR, Lemos VS, Queiroga CE, Thomas G, Medeiros IA, Cortês SF 1999. Mechanisms of the contractile effect of the hydroalcoholic extract of Cissampelos sympodialis Eichl. in rat aorta. Phytomedicine 6: 63-67.

Hill RT, Tedeshi DH 1971. Animal testing and screening procedures in evaluating psychotic drugs. In: Rech RH, Moore KE (Eds): An intoduction to psychopharmacology. Raven Press, New York, pp. 237-281.

Lechin F, Van der Dijs B, Orozco B, Jara H, Rada I, Lechón ME, Lechón AE 1998. Neuropharmachologic treatment of bronchial asthma with antidepressant tianeptine: A double-blind crossover placebo-controlled study. Clin Pharmacol Ther 64: 223-232.

Lira GA, Andrade LM, Florêncio KC, Silva MS, BarbosaFilho JM, Cunha EVL 2002. Roraimine: a bisbenzylisoquinoline alkaloid from Cissampelos sympodialis roots. Fitoterapia 73: 356-358.

Mckinney WT 1976. Animal models of depression. In: Gallant DM, Simpson GM (Eds.): Depression: behavioral, biochemical diagnostic and treatment concepts. spectrum, New York, pp. 1-77.

Melo PS, Cavalcante HMM, Barbosa-Filho JM, Diniz MFFM, Medeiros IA, Haun M 2003. Warifteine and milonine, alkaloids isolated from Cissampelo ssympodialis Eichl.: cytotoxicity on rat hepatocyte culture and in V79 cells. Toxicol Lett 142: 143-151.

Porsolt RD, Anton NB, Jalfre M 1977a. Behavioral despair in rats: a new model sensitive to antidepressant treatments. Eur J Phamacol 47: 379-391.

Porsolt RD, Bertin A, Jalfre M 1977b. Behavioral despair in mice: Primary screening-test for antidepressants. Arch Int Phar Ther 229: 327-336.

Porsolt RD, Bertin A, Jalfre M 1978. Behavioral despair in rats and mice: strain differences and the effects of imipramine. Eur J Phamacol.51: 291-294.

Porsolt RD, Mc Arthur RA, Lenègre A 1993. Psychotropic screening procedures. In: Van Haaren F (ed.) Methods in Behavioral Pharmacol. Elsevier, Amsterdam, pp 23-51.

Porto NM, Basílio IJLD, Agra MF 2008. Estudo farmacobotânico de folhas de Cissampelos sympodialis Eichl. (Menispermaceae). Rev Bras Farmacogn 18: 102-107.

Saccomano NA, Vinick FJ, Koe BK 1991. Calciumindependent phosphodiesterase inhibitors as putative antidepressants: [3-(Bicycloalkyloxy)-4methoxyphenyl]-2-imidazolidones. J Med Chem 34: 291-298.

Thomas G, Araújo CC, Agra MF, Diniz MFF, Bachelet M, Vagaftig B 1995. Preliminary studies on the hydroalcoholic extract of the root of Cissampelos sympodialis Eichl. in guinea-pig tracheal strips and bronchoalveolar leukocytes. Phytother Res 9: 473-477.

Thomas G, Selak M, Henson P 1999. The effects of an aqueous fraction of the ethanolic extract of the leaves of Cissampelos sympodialis Eichl. in human neutrophils. Phytother Res 13: 9-13.

Walsh RN, Cummins AB 1976. The open field test: A critical review. Psychol Bull 83: 1-6. 